\title{
An Integrated Framework for On-line Viral Marketing Campaign Planning
}

\author{
Patrizia Grifoni ${ }^{1}$, Alessia D'Andrea ${ }^{1} \&$ Fernando Ferri ${ }^{1}$ \\ ${ }^{1}$ National Research Council, Italy \\ Correspondence: Fernando Ferri, National Research Council, Italy. Tel: 39-649-272-4216. E-mail: \\ fernando.ferri@irpps.cnr.it
}

Received: October 24, 2012

Accepted: November 29, 2012

Online Published: December 7, 2012

doi:10.5539/ibr.v6n1p22

URL: http://dx.doi.org/10.5539/ibr.v6n1p22

\begin{abstract}
Over the years Internet marketing has become the primary tool for marketers to deliver information to consumers. It includes a mix of methods (m-marketing, social networks, viral marketing etc.) to create awareness for the company's brand, products and services. This paper, in particular addresses the on-line viral marketing method. In particular it provides a theoretical framework involving elements and actors important for the planning of an on-line viral marketing campaign. The framework presents four different phases of the analysis. The first phase involves the analysis of the company, its business context and the knowledge of the type of on-line viral marketing campaigns already done (both internal and external). In the second phase objectives and target are defined. On considering the third phase this includes the message creation and the selection of useful tolls to use. Finally in the last phase the implementation of the on-line viral marketing campaign is carried out. Each of these phases is caracterised by different actors involved in the different processes.
\end{abstract}

Keywords: marketing process, on-line viral marketing campaign, internet marketing, word-of-mouth

\section{Introduction}

Marketing is "the process which creates, communicates, delivers the value to the consumers, and maintains the relationship with consumers. It generates the strategy that underlies sales techniques, business communication, and business developments. It is an integrated process through which companies build strong consumers relationships and create value for their consumers and for themselves" (Kotler et al., 2010).

The marketing process involves the set of activities, institutions and processes for communicating, creating delivering and exchanging products/services that have value both for companies and consumers. It is one of the most important components that companies needs to address with careful attention and proactive thoughts in order to satisfy their business goals.

The advent of the Web had significant impact on the way marketers do their strategies; it provided opportunities for companies to enhance their business in a cost-effective and practical manner. The Web is used by marketers to: (i) quickly distribute products (ii) reach new markets (iii) conduct marketing researches (iv) serve consumers better (v) solve consumers' problems and (vi) communicate more efficiently with marketing partners. This evolution of marketing is called "Internet marketing". Internet marketing has been defined as "the process of building and maintaining consumers" relationships through online activities to facilitate the exchange of ideas, products, and services that satisfy the goals of both buyer and seller" (Ngai, 2003). This definition highlights the relationship building capabilities of the Internet as a marketing channel.

The widespread advent of the Internet marketing stimulated the viral marketing methods, implementing actions and strategies by self-replicating viral processes applied to on-line marketing services.

The term "viral marketing" becomes a powerful internet buzz word only in 1998, but it was pre-existing. Even if the viral marketing has grown rapidly since then, different studies still presents various definition of the term. Phelps et al. (2004) define viral marketing as "the process of encouraging honest communication among consumer networks". De Bruyn and Lilien (2004) state that viral marketing is "consumer-to-consumer (or peer-to-peer) communication, as opposed to company-to-consumer communications, to disseminate information about a product or a service, hence leading to its rapid and cost-effective market adoption". Kiss and Bichler (2008) define viral marketing as "marketing techniques that use social networks to produce increases in brand 
awareness through self-replicating viral diffusion of messages, analogous to the spread of pathological and computer viruses". This definition contains elements that characterize "viral" aspect that are both communicative and technological. On considering the communicative issue, the marketing message to become viral will reach the target of potential consumers by transforming them in active agents that involve other people by sharing the message. With respect to the technological prospective it is necessary to have flexible, easily accessible, highly integrated technologies that allow a quickly sharing of messages. The most significant benefit of viral marketing is that it allows consumers to pass along a marketing message in an easy manner by spreading it like a biological virus. The process of the viral marketing is illustrated in Figure 1.

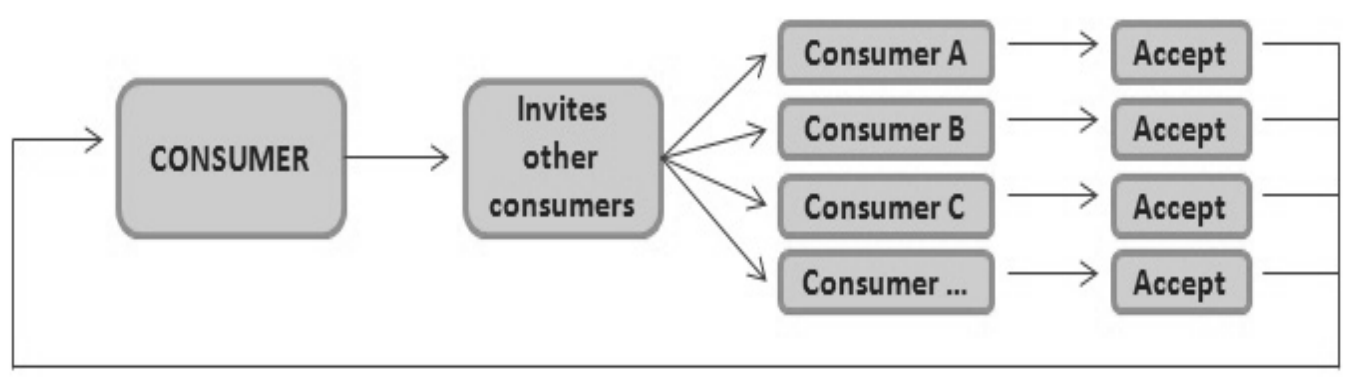

Figure 1. The viral marketing process

A consumer invites other consumers to visualize the viral message and also the products/services it illustrates; if consumers accept, they will perform the same action of the initial consumer by spreading the message to others consumers. This aspect represents an important advantage for companies to increase their sales and brand awareness or generate long-time consumer's dialogue. So it is very important for companies that want to spread their business among the target audience to plan a good on-line virtual marketing campaign. The on-line viral marketing campaign planning today presents a limited amount of literature; only a little is known about the nature, elements and dimension of viral marketing planning process (Cruz \& Fill, 2008).

Starting from these considerations, the aim of this paper is to add the existing literature by exploring in detail the process of the on-line viral marketing campaign planning. In particular the paper provides a theoretical framework that involves the elements and actors that contribute to the planning of an on-line viral marketing campaign. The framework presents four different phases of the analysis. The first phase involves the analysis of the company, its business context and the knowledge of the type of on-line viral marketing campaigns already done internal and external. In the second phase objectives and target are defined. On considering the third phase this includes the message creation and the selection of tolls to use. Finally in the last phase the implementation of the on-line viral marketing campaign is carried out. Each of these phases is caracterised by different actors involved in the different processes.

The paper is structured as follow. Section 2 provides a literature review on viral marketing. Section three introduces the framework by describing its phases. Section four concludes the paper.

\section{Method}

In order to provide the theoretical framework, the basic methodology that is applied in the paper is the literature review. In particular different aspects of viral marketing and word-of-mouth (WOM) are considered for the analysis. Viral marketing is "a broad array of online WOM strategies designed to encourage both online and peer-to-peer communication about a brand, product or service". (Golan \& Zaidner, 2008). The principle behind this form of marketing it is that of the word-of-mouth (the passing of information from person to person by oral communication). Word-of-mouth (WOM) is an essential component of public relationships, no matter what media are used (speech, text, photo, video etc.) any form of communication and information can be shared. In the marketing sector WOM communications are defined as "informal communications directed at other consumers about the ownership, usage, or characteristics of particular goods and services and/or their sellers" (Westbrook, 1987). According to the WOM Marketing Association (WOMMA), (http://womma.org/main/) WOM marketing "is giving people reasons to talk about companies, brands, products and services, and making it easier for those conversations to take place. It is a strategy where brands leverage both consumer-to-consumer and marketer-to-consumer interactions in the context of a marketing objective". Many are the studies that analyse the implications that WOM has on marketing process. Arndt (1967) was one of the first authors to 
analyse the influence of WOM on consumer behavior. He defines WOM as "oral, person-to-person communication between a receiver and a communicator whom the receiver perceives as non-commercial, regarding a brand, product or service". This definition is consistent with more recent studies about WOM marketing (Gruen et al., 2006; Wangenheim \& Bayón, 2007). Recent studies analyse the effect of consumers' satisfaction on WOM marketing (Brown et al., 2005; Söderlund, 2006). According to Ranaweera and Prabhu (2003) 'the level of consumers' satisfaction has an influence on two purchase behaviors, namely, repurchase intentions and WOM". Others studies investigate the influence of loyalty on WOM (Macintosh, 2007; Sichtmann, 2007).

The advent of the Web has changed the concept of WOM, so much so that the term "viral marketing" was coined by Steve Jurvetson in 1997 to describe hotmail's practice to append for advertising.

Today viral marketing represents a multi-disciplinary topic; many are the disciplines that analyse its advantages and limitation such as: sociology, psychology and economy.

The sociology perspective analyses the development, organization and classification of viral marketing strategies. The focus is the main platforms of the viral marketing, represented by the social media on the Internet, where people interact and exchange information like in face-to-face interactions. The only difference between face-to-face interactions and that on the Internet is that on the web the speed of information is much faster so a large number of people can be reached in a short amount of time. This represents the most significant benefit of viral marketing because allows companies to multiply the brand's popularity through consumers who spread the message. However to achieve this aim it is important that on-line viral marketing campaigns generate conversation; "viral campaign that does not encourage consumers' identification or dialogue it is simply a digital form of mass-marketing" (Ferguson, 2008).

On considering the psychology point of view, Subramani and Rajagopalan (2003) argue that "different types of viral marketing initiatives create different psychological effects to the recipients". These effects can also be observed from people's intention to share information that contributes to viral marketing's benefits in creating WOM effect (Smith et al., 2007).

According to the economic perspective, another reason that contributes to the viral marketing's popularity is "it's low-cost and high-availability, along with high supply and even higher demand (the number of people who received information from social media either directly or indirectly)" (Smith et al., 2007).

Despite the main advantages, viral marketing also presents limitations related to: technical problems or poor technological implementation (Bernoff \& Li, 2008); lack of control over message and reach (Kirby, 2006), legal issues dealing with privacy and harassment (Chaffey, 2006); lack of measurement (Cruz \& Fill, 2008) and uncharted growth in unexpected areas (Krishnamurthy, 2000). According to Gabrielsson et al. (2008) many of these limitations could be minimized if companies would do proper on-line viral marketing campaign planning. However despite the importance of the proper on-line viral marketing campaign planning, today this topic presents a limited amounts of literature; only a little is known about the nature, elements and dimension of the on-line viral marketing campaign planning (Cruz \& Fill, 2008). This aspect is better illustrated in the following section.

\section{Results}

The results of the literature review highlight limited amounts of information and studies on viral marketing campaign planning (Cruz \& Fill, 2008). Starting from these considerations, the aim of this paper is to improve the existing literature by exploring in detail the process of the on-line viral marketing campaign planning. To do this a theoretical framework that involves the elements and actors that contribute to the planning of an on-line viral marketing campaign is provided and described in detail.

An on-line viral marketing campaign is the starting point for companies to develop marketing communication strategies and spread their business among the target audience. It offers companies a wealth of information that, if correctly applied, can ensure the company success. In this section an integrated framework for on-line viral marketing campaign planning is provided. The framework (shown in Figure 2) includes the following phases:

- phase 1: company, business context and virtual campaigns already done are analysed;

- phase 2: objects and target are defined;

- phase 3: message is created and tools are selected;

- phase 4: the on-line viral marketing campaign is implemented. 


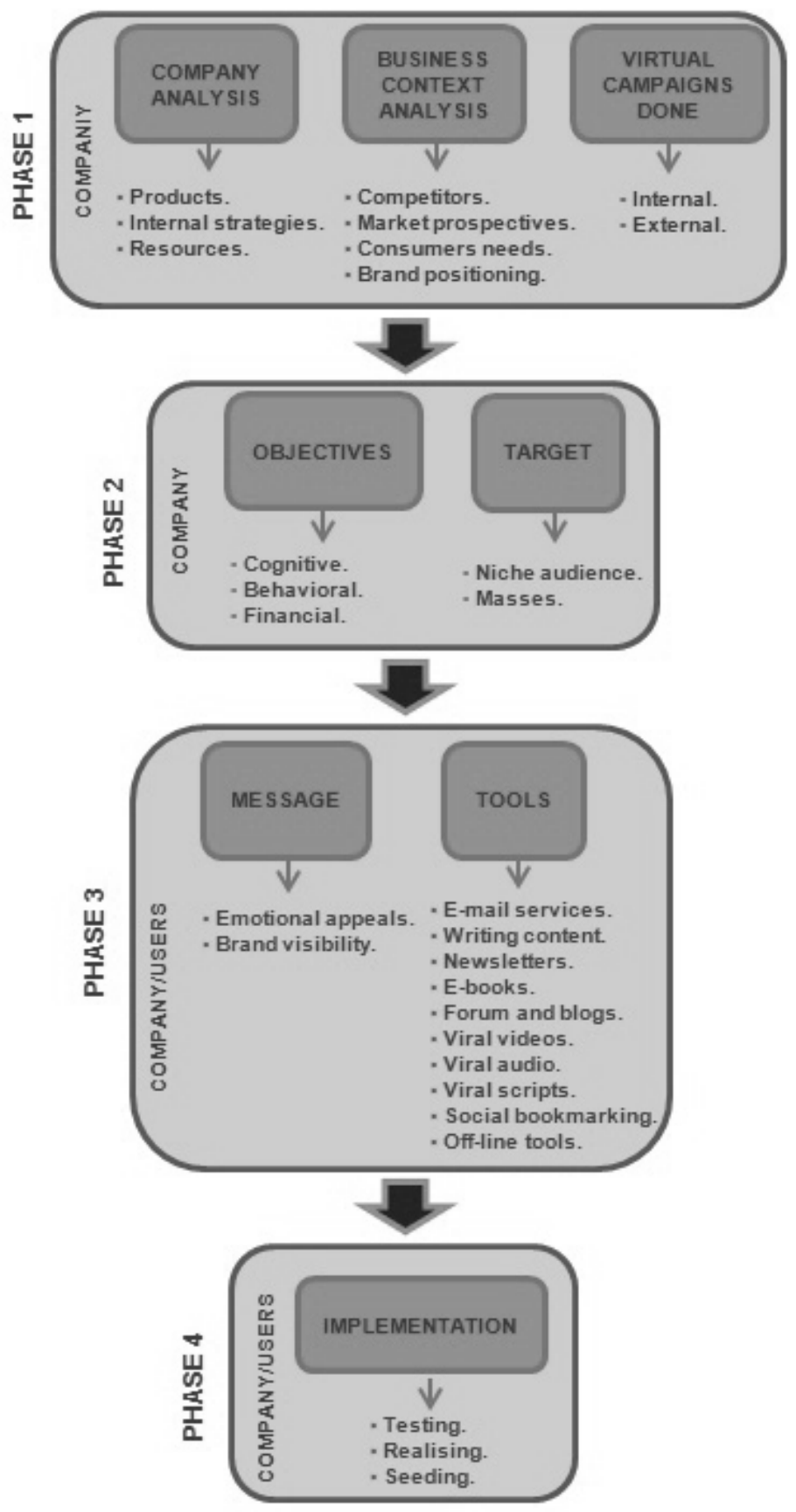

Figure 2. The integrated framework for on-line viral marketing campaign planning

\subsection{Phase 1}

The first phase of the framework has an important impact on the design and development of the on-line viral marketing campaign. According to Gabrielsson et al. (2008) "a viral campaign should begin with an analysis of the company and its business context" that includes both internal factors, such as products, internal strategy and resources of the company and external factors, such as competitors, market prospective, consumer needs and brand positioning. The analysis of product(s) currently offered by company includes a description of (i) main products features and benefits (ii) pricing used at all distribution levels (from distributors to final users) (iii) how products are made accessible to final users (iv) promotional programs and advertising strategies (v) support offered to final users. On considering the internal strategies of the company these indicate the direction of the company over the long-term. These represent potential advantages for the company to meet the needs of markets and to fulfil stakeholder expectations. Internal strategies exist at several levels in any company; there are: (i) 
strategies at corporate level that are concerned with the overall scope of the marketers to meet stakeholder expectations (ii) business unit strategies that analyses how the company competes in a particular market (iii) operational strategies that indicate how each part of the company is organised to deliver the corporate and marketing-unit level strategic direction.

The analysis of products and internal strategies are influenced by resources that are at the disposal of the company. The resources that normally depend upon the particular company's business performance can be acquired by various business activities. The analysis of internal factors allows marketers to define the financial plan that establishes if the company's idea is viable or not so it is a key component in determining if the on-line viral marketing campaign is going to be able to attract any investment in the company marketing idea.

Basically, the financial plan consists of three-steps that help companies to look at where they financially are and where they want to be. These steps are the following:

- collection of financial data - such as details on companies income and expenses, debt level, commitments, etc.;

- identification of companies goals and objectives;

- identification of any financial problems.

To evaluate the feasibility of the on-line viral marketing campaign, companies have to consider also external factors (business context analysis). Firstly companies must analyse how they can cope with competitors in particular on considering:

- how often competitors improve or replace their products/services?

- what is their market share?

- how they promote their products/services?

- how widely do they advertise their products/services?

- what is their reputation among consumers?

The market perspectives deal with consumers and demand uncertainties. Its analysis is vital because, the success of any company depends on its ability to create and maintain relationships with consumers by offering suitable value propositions that provide an answer to their needs. In fact consumers determine the success of any marketing strategies; they make the decision on whether to purchase products or not; thus they are the target of marketing strategies. From an economic perspective, consumer needs control the demands for products; these needs may include wishes and desires, unique wants as well as emotional attachments towards products. Finally the brand positioning is a medium through which a company can portray its consumers what it wants to achieve for them and what it wants to mean to them. A strong brand positioning directs the on-line viral marketing campaign by explaining the brand details its uniqueness and it's similarity with the competitive brands.

Also, before making any crucial decisions on the on-line viral marketing campaign planning, the company should have an idea on the type of on-line viral marketing campaigns its already done both internal (on considering examples of successfulness past campaigns implemented for existing products) and external (on-line viral marketing campaign done by competitors to individuate what is feasible, and what the current trends are).

\subsection{Phase 2}

The second phase of the framework involves the definition of the objectives and the selection of the target. The objectives setting is one of the most important parts of the whole framework because the objectives influence the existence of the on-line viral marketing campaign, from planning to evaluation. For setting objectives one of the only existing models specifically created for the on-line viral marketing campaign is that introduced by Cruz and Fill (2008). The model involves three categories of objectives: cognitive (evaluated in terms of reach and awareness), behavioral (evaluated in terms of hits or downloads) and financial (evaluated in terms of brand building). Hollensen (2007) defines "reach" as a potential campaign objective by and while mention increased awareness and interest, which could be also categorized as reach objectives. Keller and Berry (2003) suggest that "increased brand awareness comes with three main advantages: the ability to influence consumer learning, consideration, and choice". While the concept of brand building as a campaign objective is carried out by Leppäniemi and Karjaluoto (2008), in regard to mobile on-line viral marketing campaigns. Once defined the objectives, targeting the right people is a crucial element in on-line viral campaign planning in fact "a well-targeted on-line viral marketing campaign is more likely to generate a positive response in the recipient" (Dobele et al., 2007). There are two different possibilities for company: to target a niche audience or to target the masses (Cruz \& Fill, 2008). Consumers can be classifying according to the following classes: 
- profile

- psychological

- behavioural

The profile class involves demographic, life-stage and geographic characteristics. In particular demographic characteristics concern sex, age, occupation, social class, level of education which determines a potential buyer's ability to purchase products/services. Life-stage is based on the principle that people need different products/services at different stages in their lives (e.g. childhood, adulthood) while the different geographic define the needs of potential consumers; this may be due to climate, tradition, custom etc. The psychological class involves lifestyles and benefits sought characteristics. The lifestyle characteristic refers to consumers' interests, activities and opinions that affect their buying behaviour and decision-making processes. While the benefits sought characteristics derive from the analysis of the motivations that lead consumers to sale particular products/services. The behavioural class includes the purchase/transaction, product usage and media usage characteristics. The purchase/transaction characteristic allows analysing who buys what, when, how often, how much they spend, and through what transactional channel they purchase while the product usage refers to data on usage frequency, time of usage, and usage situations of particular products/services.

\subsection{Phase 3}

The third phase of the framework includes the creation of the message and the selection of tools to use. Keeping the overall marketing objectives in mind, the message is created for the chosen target group. Many are the attributes that the message has to contain in order to rapidly spread among the target audience. According to (Lindgreen \& Vanhamme, 2005) it should contain various emotional appeals, such as humor and surprise; emotional appeals tend to influence forwarding behaviour. Another interesting aspect of message creation is the brand visibility: "if the campaign is overtly branded, consumers may find it off-putting, but if it is too subtle, the company may not get much credit for the on-line viral marketing campaign" (Chaffey, 2006). At this point, after the message has been crated, it is important to select the right tools. The selection of tools is based on consumer needs (Rappaport, 2007) and usability (Lindgreen \& Vanhamme, 2005). One of the most popular examples of a successful on-line viral marketing campaign is those that use email services like Hotmail that allow to send e-mails in large numbers to a huge population. Another best ways of doing viral marketing for company is by writing content and publishing it on their own or others web site. Also newsletters can be publishing. If newsletters have information that interest consumer who subscribe to it, there are higher chances that they will forward this also to consumers within social networks. It is also possible to make use of e-books that can help generate a huge number of visitors to their own web site. E-books can be easily created by company than can sell them with resale rights. The person who purchases the resale right for the e-book will then sell it to another person and this person will, again, sell to another. Traditional tools like forum and blogs are also used because allow their members to be a part of a group that shares something in common. Marketing through videos is another import tool that has gained immense popularity. The emergence of sites like Google Videos and YouTube has made it fairly simple to post these videos online. Quite similar to viral videos are the viral Audio that offers the possibility to record voice and send it over to as many people as possible. Also viral scripts are used that are software program codes placed on website that allow users who visit the web site to email something or an entire webpage to a whole lot of their friends. These tolls are results of the Web 2.0. development like social bookmarking, a toll fairly easy to use: a user of this system only saves the links to certain webpage's, which he/she wishes to remember or share with others. Many are companies that use these methods together with products offline tools. This represents a great way to increase the brand awareness. This technique can also be very successful because of the fact that not the whole of the targeted population of the consumers is expected to be online everyday and even if they are online not all of them really care.

\subsection{Phase 4}

Finally the last phase of the framework includes the testing, realising and seeding of the on-line viral marketing campaign. Before the on-line viral marketing campaign can be fully implemented a campaign testing is recommended (Spencer \& Giles, 2000; Lindgreen \& Vanhamme, 2005; Gabrielsson et al., 2008). Spencer and Giles (2000) suggest that all on-line viral marketing campaign should be tested with a "micro" target in order to cover target expectations, consumer's likes and dislikes, reactions to the planned offer etc. After the campaign was tested, it is released and seeded. Hollensen (2007) defines the seeding process as "the act of planting the campaign with the initial group who will then go on to spread the campaign to others". That seeding can happen, for instance, via online forums, social networks, email, but the mostly diffused are blogs. etc.. The company 
benefits from the feedback it receives from the bloggers, allowing it to make any necessary changes before the on-line viral marketing campaign site becomes publicly available.

\section{Discussion}

The paper provides a theoretical framework that involves the elements and actors that contribute to the planning of an on-line viral marketing campaign. The motivation for the provided framework comes from a research gap in the existing literature with respect to the process of on-line viral marketing campaign planning. The provided framework presents four different phases of the analysis.

The first phase involves the analysis internal factors, (such as products, internal strategy and resources of the company) and external factors (competitors, market prospective, consumer needs and brand positioning). The analysis of internal factors allows marketers to define the financial plan that allows to establish if the companies idea is viable or not, and it is a key component in determining if the on-line viral marketing campaign is going to be able to attract any investment in the company marketing idea. While the analysis of external factors allows to evaluate the feasibility of the on-line viral marketing campaign. An important role is also assigned to the analysis of on-line viral marketing campaigns already done both internal (on considering examples of successfulness campaign) and external (on-line viral marketing campaign done by competitors to individuate what is feasible, and what the current trends are).

In the second phase of the framework objectives and target are defined. Objectives are classified in three categories according to the model proposed by Cruz and Fill (2008): cognitive (evaluated in terms of reach and awareness), behavioral (evaluated in terms of hits or downloads) and financial (evaluated in terms of brand building). Once defined the objectives, targeting the right people is a crucial element in on-line viral campaign planning. There are two different possibilities for company: to target a niche audience or to target the masses.

On considering the third phase this includes the message creation and the selection of tolls to use. Different studies in the literature suggest that many the attributes that the message has to contain in order to rapidly spread among the target audience are emotional appeals and brand visibility. While on considering the selection of tools this should be based on consumer needs and usability. Many are tolls that companies but also consumers can use to rapidly spread products information such as: e-mail services, writing content on web sites; newsletters, e-books, forums and blogs; viral videos, audio and scripts; social bookmarking and off-line tools.

Finally the last phase involves the implementation of the on-line viral marketing campaign that involves the testing, realising and seeding of the on-line viral marketing campaign. Before the on-line viral marketing campaign can be fully implemented a campaign testing is recommended. After the campaign was tested, it is released and seeded. That seeding can happen, for instance, via online forums, social networks, email, but the mostly diffused are blogs. etc..

The framework only considers the planning process of the on-line viral marketing campaign. Future works will address the extension of the framework also to the on-line viral marketing campaign evaluation. In particular, to model the process of adoption of products/services viral diffusion models such as threshold model (Granovetter, 1978) and cascade model (Goldenberg et al., 2001) will be applied. As for the planning process, also the measurement and evaluation processes of the on-line viral marketing campaign present a limited amount of literature (Cruz \& Fill, 2008). It is very important for companies that implement on-line viral marketing campaign to deliver visible results so the measurement and evaluation those results can be very challenging. The difficulty is that the lack of research around these topics makes difficult to determine which measures and evaluation methods can be favored by marketers. Even if online tracking tools made easy the measurement marketing campaign success, they are not sufficient to completely measure and evaluate on-line viral marketing campaigns.

\section{References}

Arndt, J. (1967). Role of product- related conversations in the diffusion of a new product. Journal of Marketing Research, 4, 291-295. http://dx.doi.org/10.2307/3149462

Bernoff, J., \& Li, C. (2008). Harnessing the Power of the Oh-So-Social 134 Web. MIT Sloan Management Review, 49(3), 36-42.

Brown, T. J., Barry, T. E., Dacin, P. A., \& Gunst, R. F. (2005). Spreading the word: investigating antecedents of consumers' positive word-of-mouth intentions and behaviors in a retailing context. Journal of the Academy of Marketing Science, 33(2), 123-138. http://dx.doi.org/10.1177/0092070304268417

Chaffey, D. (2006). Total E-mail Marketing (2nd ed.). Butterworth-Heinemann, Oxford, England. 
Cruz, D., \& Fill, C. (2008). Evaluating Viral Marketing: Isolating the Key Criteria. Marketing Intelligence \& Planning, 26(7), 743-758. http://dx.doi.org/10.1108/02634500810916690

De Bruyn, A., \& Gary, L. L. (2004). A Multi-Stage Model of Word of Mouth Through Electronic Referrals. eBusiness Research Center Working Paper.

Dobele, A., Lindgreen, A., Beverland, M., Vanhamme, J., \& Van Wijk, R. (2007). Why Pass on Viral Messages? Because They Connect Emotionally. Business Horizons, 50, 291-304. http://dx.doi.org/10.1016/j.bushor.2007.01.004

Ferguson, R. (2008). Word-of-Mouth and Viral Marketing: Taking the Temperature 137 of the Hottest Trends in Marketing. Journal of Consumer Marketing, 25(3), 179-182. http://dx.doi.org/10.1108/07363760810870671

Gabrielsson, P., Gabrielsson, M., \& Gabrielsson, H. (2008). International Advertising Campaigns in Fast-Moving Consumer Goods Companies Originating from a SMOPEC Country. International Business Review, 17(6), 714-728. http://dx.doi.org/10.1016/j.ibusrev.2008.09.008

Golan, G. J., \& Zaidner, L. (2008). Creative strategies in viral advertising: an application of Taylor's six-segment message strategy wheel. Journal of Computer-Mediated Communication, 13(4), 959-972. http://dx.doi.org/10.1111/j.1083-6101.2008.00426.x

Goldenberg, J., Libai, B., \& Muller, E. (2001). Talk of the network: A complex systems look at the underlying process of word-of-mouth. Market. Lett., 3(12), 211-223. http://dx.doi.org/10.1023/A:1011122126881

Granovetter, M. (1978). Threshold models of collective behavior. Ameri. J. Sociol., 83(6), 1420-1443. http://dx.doi.org/10.1086/226707

Gruen, T. W., Osmonbekov, T., \& Czaplewski, A. J. (2006). eWOM: the impact of customer-to-customer online know-how exchange on customer value and loyalty. Journal of Business Research, 59(4), 449-456. http://dx.doi.org/10.1016/j.jbusres.2005.10.004

Hollensen, S. (2007). Global Marketing: A Decision-Oriented Approach (4th ed.). England Hung: Pearson Education Unlimited, Essex.

Keller, E., \& Berry, J. (2003). The Influentials: One American in Ten Tells the Other Nine How to Vote and What to Buy. The Free Press, New York, USA Keller.

Kiss, C., \& Bichler, M. (2008). Identification of Influencers - Measuring Influence in Customer Networks. Decision Support Systems, 46(1), 233-253. http://dx.doi.org/10.1016/j.dss.2008.06.007

Kotler, P., Armstrong, G., Wong, V., \& Saunders, J. (2010). Marketing defined. Principles of marketing. Retrived from: http://books.google.com/books?id=6T2R0_ESU5AC\&lpg=PP1\&pg=PA7\#v=onepage\&q=\&f=true.

Krishnamurthy, S. (2000). Is Viral Marketing All It's Cracked Up to Be?. Available at: http://www.clickz.com/823941.

Leppäniemi, M., \& Karjaluoto, H. (2008). Mobile Marketing: From Marketing Strategy to Mobile Marketing Campaign Implementation. International Journal of Mobile Marketing, 3(1), 50-61.

Lindgreen, A., \& Vanhamme, J. (2005). Viral marketing: The Use of Surprise. In Irvine C. Clarke \& Theresa B. Flaherty (Eds.), Advances in Electronic Marketing (pp. 122-138). Hershey, PA: Idea Group. http://dx.doi.org/10.4018/978-1-59140-321-0.ch007

Macintosh, G. (2007). Customer orientation, relationship quality, and relational benefits to the firm. Journal of Services Marketing, 21(3), 150-159. http://dx.doi.org/10.1108/08876040710746516

Ngai, E. W. T. (2003). Internet Marketing Research: A Literature Review and Classification. European Journal of Marketing, 37(1/2), 24-49. http://dx.doi.org/10.1108/03090560310453894

Phelps, J. E., Lewis, R., Mobilio, L., Perry, D., \& Raman, N. (2004). Viral Marketing or Electronic Word-of-Mouth Advertising: Examining Consumer Responses and Motivations to Pass Along Email. Journal of Advertising Research, 44(4), 333-348.

Ranaweera, C., \& Prabhu, J. (2003). On the relative importance of customer satisfaction and trust as determinants of customer retention and positive word of mouth. Journal of Targeting, Measurement and Analysis of Marketing, 12(1), 82-90. http://dx.doi.org/10.1057/palgrave.jt.5740100

Rappaport, S. D. (2007). Lessons from Online Practice: New Advertising Models. Journal of Advertising Research, 47(2), 135-141. http://dx.doi.org/10.2501/S0021849907070158 
Sichtmann, C. (2007). An analysis of antecedents and consequences of trust in a corporate brand. European Journal of Marketing, 41(9/10), 999-1015. http://dx.doi.org/10.1108/03090560710773318

Smith, T., Coyle, J. R., Lightfoot, E., \& Scott, A. (2007). Reconsidering Models of Influence: The Relationship between Consumer Social Networks and Word-of-Mouth Effectiveness. Journal of Advertising, 144 Research, 47(4), 387-397. http://dx.doi.org/10.2501/S0021849907070407

Söderlund, M. (2006). Measuring customer loyalty with multi-item scales - a case for caution. International Journal of Service Industry Management, 17(1), 76-98. http://dx.doi.org/10.1108/09564230610651598

Spencer, C., \& Giles, N. (2000). The Planning, Implementation and Evaluation of an Online Marketing Campaign. Journal of Communication Management, 5(3), 287-299. http://dx.doi.org/10.1108/13632540110806839

Wangenheim, F. V., \& Bayón, T. (2007). The chain from customer satisfaction via word-of-mouth referrals to new customer acquisition. Journal of the Academy of Marketing Science, 35(2), 233-249. http://dx.doi.org/10.1007/s11747-007-0037-1

Westbrook, R. A. (1987). Product/consumption based affective responses and postpurchase processes. Journal of Marketing Research, 24(3), 258-270. http://dx.doi.org/10.2307/3151636 